\title{
Stage IV Gastric Neuroendocrine Tumor AJCC v8
}

National Cancer Institute

\section{Source}

National Cancer Institute. Stage IV Gastric Neuroendocrine Tumor A/CC v8. NCI

Thesaurus. Code C135049.

Stage IV includes: (T1, N0, N1, M1); (T2, N0, N1, M1); (T3, N0, N1, M1); (T4, N0, N1, M1).

T1: Tumor invading the lamina propria or submucosa and is less than or equal to $1 \mathrm{~cm}$ in size. T2: Tumor invading the muscularis propria or is greater than $1 \mathrm{~cm}$ in size. T3:

Tumor invading through the muscularis propria into subserosal tissue without penetration of overlying serosa. T4: Tumor invading visceral peritoneum (serosa) or other organs or adjacent structures. N0: No regional lymph node metastasis. N1:

Regional lymph node metastasis. M1: Distant metastasis. (AJCC 8th ed.) 